Victoria and Albert Museum. C.M.G. : A. J. Findlay, director of agriculture, Zanzibar ; C. F. M. Swynnerton, director of tsetse research, Tanganyika Territory. C.I.E. : J. F. Blakiston, director-general of archæology in India; Colonel J. Taylor, director, Central Research Institute, Kasauli ; Lieut.-Colonel C. Newcomb, chemical examiner to the Government of Madras, and principal, Medical College, Madras; F. Ware, officiating expert adviser in animal husbandry to the Imperial Council of Agricultural Research.

C.B.E. : Prof. A. L. Bowley, emeritus professor of statistics in the University of London; Prof. E. L. Collis, emeritus professor of preventive medicine in the University of Wales, a member of the Miners' Welfare Committee ; G. S. Colman, member of the Pastoral Research Council, Commonwealth of Aus tralia; Dr. A. D. Crow, director of ballistics research, Research Department, Royal Arsenal, Woolwich; Colonel J. Heatly-Spencer, honorary physician to the King, professor of tropical medicine, Royal Army Medical College, and consulting physician to the Army.

O.B.E.: W. P. Brewis, chairman of the Newcastle Society of Antiquaries, member of the Council of the Roman Society; H. J. Burrell, for contributions to natural history in the Commonwealth of Australia; R. Daubney, chief veterinary research officer, Kenya; H. N. Linstead, secretary and registrar of the Pharmaceutical Society of Great Britain; A. Main, chief inspector of agriculture, Department of Agriculture for Scotland; A. Morley, lately staff inspector, Board of Education; Prof. A. J. Perkins, formerly director of agriculture in the State of South Australia; F. S. Richards, deputy surveyor-general to the Egyptian Government; H. W. Simmonds, entomologist, Fiji ; Dr. J. M. Stagg, senior technical officer, Meteorological Office, Air Ministry; D. Stewart, deputy conservator of forests, United Provinces; J. G. Stewart, chief inspector of agricultural educa. tion, Ministry of Agriculture and Fisheries. M.B.E. : W. L. Watt, agricultural cfficer, Kenya; L. F. Wacher, agricultural officer, Basutoland. I.S.O. : A. H. Cockayne, director-general, Department of Agriculture, Dominion of New Zealand; A. More, deputy Government chemist.

\section{Prof. W. L. Bragg, O.B.E., F.R.S.}

Prof. W. L. BraGG, who has been appointed director of the National Physical Laboratory, has held the Langworthy chair of physics in the University of Manchester since 1919. Beginning his research work at Cambridge in 1912, about the time when v. Laue had announced his discovery of the diffraction of X-rays by crystals, Prof. Bragg was attracted to this field of work. One of his early papers explained, in terms of the 'reflection' principle, the nature of the patterns observed in the Laue photographs. Along with his father, Sir William Bragg, he developed the X-ray spectrometer. The determination of the structures of the simpler crystals followed, until in 1915 , their work was recognized by the joint award of the Nobel Prize for Physics. After his appoint- ment at Manchester, Prof. Bragg quickly established a school of workers engaged in investigations of the solid state of matter. His own particular interest has been in the orderly arrangement of atoms in crystals and in relations between atomic arrangement and the properties of a crystalline substance. The field is a very wide one, and is of interest, not only to the physicist, but also to the chemist who is seeking to understand the nature of the forces which bind atoms together and to the industrial research worker who wants information about the structure of his working materials.

Following the first period, in which the simpler crystal structures were investigated by X-ray methods, the determination of the structures of more complex crystals was made possible, principally through the development of methods of analysis using the intensities as well as the directions of reflection of the X-rays. In this phase of the work, Prof. Bragg and his co-workers have determined a range of complex structures of minerals, particularly silicates and zeolites. During the last few years, Prof. Bragg and his team of research workers have been particularly interested in an experimental and theoretical study of the atomic arrangements in alloys and in the effect of heat treatment on these structures. Prof. Bragg's laboratory in Manchester has been one of the principal centres in Great Pritain for the investigation of the structure of crystals, and students from all parts of the world have visited the laboratory, either for training in this field of research or for the privilege of working under Prof. Bragg's supervision.

\section{Prof. A. O. Rankine, O.B.E., F.R.S.}

IT is announced that Prof. A. O. Rankine, professor of physics in the Imperial College of Science and Technology since 1919 , will resign that position at the end of the present academic year in order to join the staff of the Anglo-Iranian Oil Company as chief physicist. Prof. Rankine has for some years acted as geophysical adviser to the Company and in his new position he will take charge of all physical investigations carried out by the Company. The appointment is another interesting and significant example of the migration from the academic to the industrial world of a distinguished man of science, and is evidence of the ever-growing importance of science and scientific research in modern industrial development. It may be remembered that Sir John Cadman, the chairman of the Anglo-Iranian Oil Company, was himself at one time a professor in the University of Birmingham. During his chairmanship of the Company, since 1927, notable work in the development of the relatively new science of geophysics has been carried out since 1924 by the Company, which introduced geophysical surveying in the country formerly known as Persia and now to be called Iran. In the development of geophysical science, Prof. Rankine has played a notable part, and will no doubt find in his new sphere increased scope and opportunity for further advances. 